\title{
ANALYSIST OF WEB-BASED LAUNDRY INFORMATION SYSTEM
}

\author{
Indah Cyithia Devi $^{1)}$, Farah Hana Zhafirah ${ }^{2)}$, Rida Indah Fariani ${ }^{3)}$ \\ Program Studi Sistem Informasi, Politeknik Manufaktur Astra \\ Komplek Astra International Tbk, Gedung - B, \\ Jl. Gaya Motor Raya No. 8, Sunter, Jakarta 14330 \\ Email : ${ }^{1}$ Indah.cyithiadevi@ polman.astra.ac.id
}

\begin{abstract}
Laundry is business engaged in services that are now commonly found. The high demand for laundry services makes laundry owners in Sungai Bambu, North Jakarta look for ways to keep transaction records neatly organized and not lose records or damage that is often experienced by customers or owners. In addition, employees must calculate the total price of the weight of the items to be washed, so that it takes a long time. Laundry also provides a variety of laundry services that can be added at any time. Besides making manual reports. To overcome this, laundry service information system is designed using the waterfall method built with Visual Studio as an interface and SQL Server as data storage. Design of this information system will make it easy to collect transaction data and minimize data loss or damage, generate automatic reports, and can perform special laundry services.
\end{abstract}

Keywords: Visual Studio, SQL Server, waterfall.

\section{Pendahuluan}

Laundry merupakan salah satu penyedia jasa cucian yang sekarang ini sudah banyak ditemukan, beberapa laundry di daerah Sungai Bambu, Jakarta Utara ini tidak hanya menyediakan jasa cuci pakaian, namun menyediakan berbagai layanan jasa cucian seperti helm, sepatu, dan lainnya yang sewaktu-waktu dapat ditambahkan. Dalam menjalankan bisnisnya laundry melakukan pencatatan masih menggunakan cara manual, contohnya proses pencatatan transaksi pencucian barang yang dilakukan oleh pelanggan kepada pegawai atau karyawan. Proses transaksi ini memakan waktu yang lama karena pegawai atau karyawan harus menghitung harga berat barang pelanggan yang akan dicuci. Hal ini rawan terjadi kesalahan atau kecurangan dalam menghitung total harga berat barang yang akan dibayar oleh pelanggan. Selain itu apabila terjadi banyak transaksi pencucian, maka pegawai atau karyawan yang menangani akan mengalami kesulitan dalam melakukan kontrol sehingga akan menimbulkan kesalahan dalam pencatatan nota atau transaksi. Selain pencatatan proses transaksi, pembuatan laporan pun masih menggunakan cara manual, sehingga hal ini dapat menyebabkan kerusakan atau hilangnya data yang dicatat.

Berdasarkan permasalahan tersebut, maka diperlukan suatu sistem yang mampu menyimpan dan mengolah data dengan baik, cepat dan mudah. Pengolahan data akan dilakukan secara otomatis oleh sistem sehingga data dapat tersimpan dengan baik dan menghasilkan laporan yang akurat untuk membantu manager dalam melihat laporan pendapatan yang dihasilkannya. Oleh karena itu, perlu dibangun sebuah sistem informasi berbasis web yang nantinya diharapkan dapat menunjang aktivitas dan keberhasilan bisnis pada jasa laundry.

Penelitian sejenis juga pernah dilakukan oleh beberapa peneliti. Sistem informasi jasa laundry berbasis web dapat membantu masyarakat yang ingin mencari laundry dan ingin mendaftarkan outletnya sebagai penyedia jasa laundry di daerah Makassar [3]. Aplikasi ini dapat memberikan informasi up-to-date tentang jasa yang cepat dan terpercaya kepada pelanggan, memudahkan proses pembuatan laporan pendapatan dengan cepat, tepat dan 
akurat, memberikan pelayanan yang professional kepada pelanggan dan meminimalisir kesalahan-kesalahan yang mungkin terjadi[4]. Aplikasi antar-jemput laundry pada platform Android yang digunakan untuk mendata pakaian yang masuk dan keluar maupun mendata pelanggan yang akan menggunakan jasa laundry secara tepat waktu[5]. Sistem informasi berbasis web yang dilengkapi aplikasi mobile yang dapat diakses oleh pengguna tanpa batasan waktu dan tempat[6]. Tapi yang membedakan penelitian ini dengan penelitian sebelumnya adalah terdapat custom produk yang boleh di laundry(tidak hanya pakaian).

\section{Metodologi Penelitian}

Penelitian ini dimulai dari melalukan survey di lapangan pada laundry yang ada di daerah Sungai Bambu, Jakarta Utara, kemudian hasil survey dibuat perumusan masalah, kemudian dibandingkan dengan beberapa penelitian lain untuk menentukan tujuan, kemudian mengumpulkan data untuk diolah, selanjutnya dianalisa untuk ditarik kesimpulan dan sarannya[9]. Diagram alir penelitian dapat dilihat pada Gambar 1.

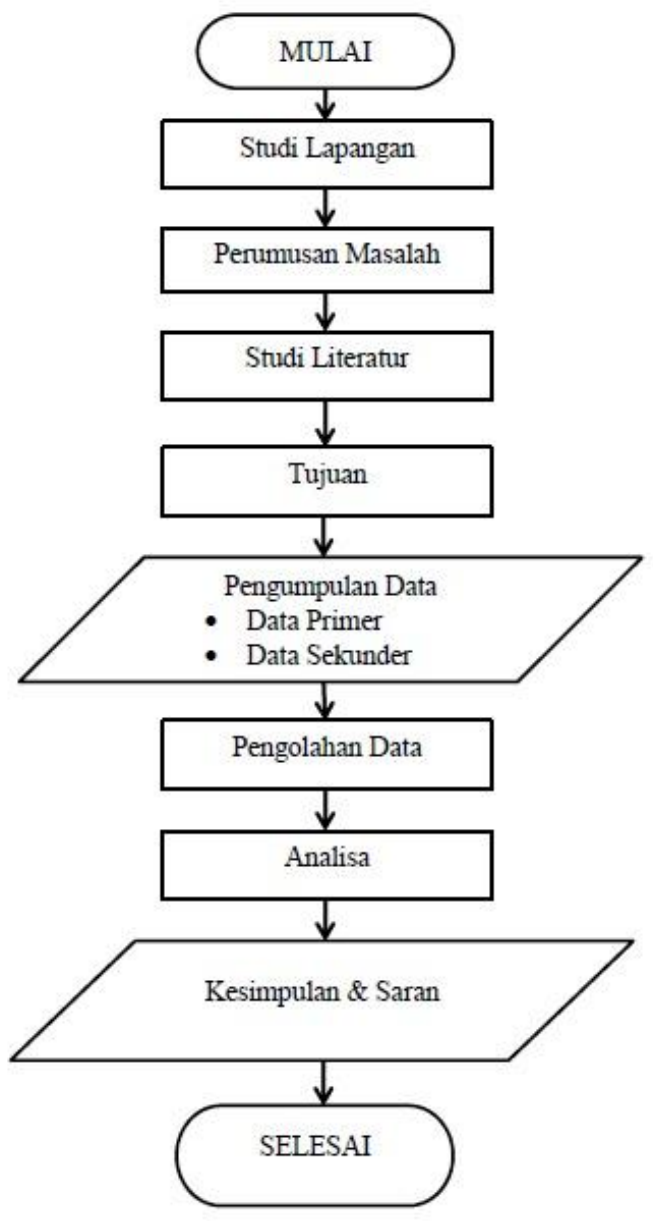

Gambar 1 Diagram alir penelitian

Metode yang digunakan untuk membuat sistem informasi ini adalah System Development Life Cycle (SDLC) dengan metodologi waterfall development model. SDLC merupakan proses bagaimana sistem informasi dibangun sesuai dengan rancangan atau kebutuhan bisnis dari pengguna yang prosesnya dilakukan secara bertahap. SDLC memiliki empat fase dasar atau tahapan yaitu perencanaan(planning), analisis(analysist), perancangan(design), implementasi(implementation), dan system[10]. 
Model waterfall atau Classic Life Cycle dan atau dapat disebut model air terjun adalah pengembangan sistem informasi yang menggambarkan metode pengembangan linier dan berurutan yang harus dilakukan dengan cara menyelesaikan secara bertahap untuk lanjut ke tahapan berikutnya mulai dari kebutuhan sistem selanjutnya ke tahap planning, analysist, design, implementation, system. Ruang lingkup sistem laundry ini sudah jelas dan umum, sehingga diputuskan untuk menggunakan metodologi tersebut. Tahapan dari waterfall dapat dilihat pada Gambar 2.

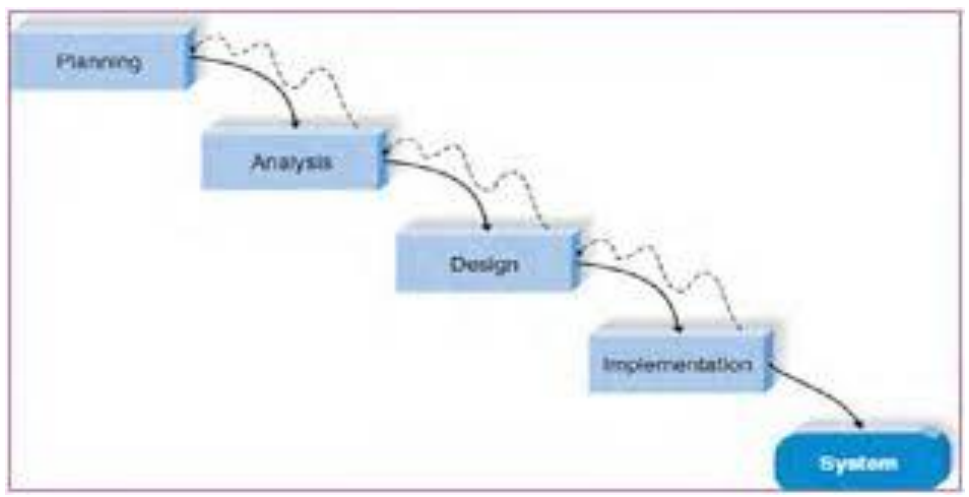

Gambar 2 Flow Waterfall Model

Berikut penjelasan dari Gambar 2 adalah sebagai berikut :

1. Perencanaan (Planning)

Dalam tahapan ini, menjelaskan proses mendasar untuk mengetahui mengapa sistem informasi ini harus dibangun. Dari tahap planning ini akan ditentukan secara detail rencana kegiatan yang harus dikerjakan, durasi yang diperlukan masing-masing tahapan[11].

2. Analisis (Analysist)

Tahap kedua, adalah tahap analisis, yaitu tahap dimana kita berusaha untuk mengenali permasalahan yang muncul pada pengguna.Tujuan utama dari tahap analisis adalah untuk mendokumentasikan kebutuhan bisnis dari sistem yang akan dibangun.Tahapan ini dilakukan berdasarkan tahap perencanaan sebelumnya.

3. Perancangan (Design)

Tahap design dilakukan untuk mencari solusi dari permasalahan yang didapat dari tahap analisis. Tahapan ini mengubah dari kebutuhan yang masih berupa konsep menjadi perancangan sistem yang akan dibangun, baik menentukan perangkat keras, perangkat lunak, desain antarmuka, dan basisdata yang akan digunakan.

4. Implementasi (Implementation)

Pada tahap implementation, dilakukan penerapan dari tahap-tahap sebelumnya yaitu mengimplementasikan perancangan sistem ke dalam bentuk kode program(coding) dan pengujian(testing) serta perbaikan aplikasi.

5. Sistem (System)

Pada tahap sistem, dilakukan pemeliharaan, yang bertujuan untuk menentukan apakah sistem yang dibangun sudah sesuai kebutuhan pengguna atau belum. Selain itu juga bertujuan untuk menjaga sistem agar berjalan dengan baik.

\section{Hasil dan Pembahasan}

\subsection{Gambaran Umum Aplikasi}

Sistem informasi ini dibangun menggunakan bahasa ASP.NET dan menggunakan SQL Server sebagai tempat penyimpanan data. Aplikasi ini diharapkan dapat mempermudah proses transaksi bisnis yang ada dalam laundry. Aplikasi ini dapat diakses oleh admin untuk 
menambahkan master layanan laundry, master pelanggan, serta pegawai (kasir, pencuci, penyetrika, dan kurir), selain itu aplikasi ini juga dapat diakses oleh pelanggan yang akan menggunakan jasa laundry, pegawai kasir untuk melakukan konfirmasi pembayaran, pegawai pencuci untuk melakukan konfirmasi barang yang sudah selesai dicuci, pegawai penyetrika untuk melakukan konfirmasi barang yang sudah selesai disetrika, dan kurir untuk konfirmasi pengambilan dan pengantaran barang yang di laundry.

Proses bisnis aplikasi laundry ini diawali dengan pelanggan yang melakukan pemesanan jasa laundry melalui aplikasi dengan login atau registrasi jika belum terdaftar kemudian mengisi data laundry dan alamat untuk pengambilan atau pengantaran oleh kurir, kemudian pelanggan melakukan konfirmasi pembayaran bukti transfer atau bayar ditempat, pegawai kasir akan melakukan pengecekan untuk kemudian dikonfirmasi jika pembayaran sesuai dan akan dilanjutkan pengambilan barang oleh kurir ke pelanggan, kurir akan melakukan konfirmasi selesai jika sudah dilakukan pengambilan barang, barang yang diambil akan masuk ke proses selanjutnya yaitu pencucian, dimana pencuci akan melakukan konfirmasi jika barang sudah selesai dicuci, proses selanjutnya barang yang selesai dicuci akan disetrika dan penyetrika akan melakukan konfirmasi juka barang sudah selesai di setrika, kemudian kurir akan mengantarkan kembali barang yang selesai di laundry kepada customer, proses bisnis aplikasi laundry ini akan menghasilkan riwayat pemesanan jasa laundry yang dapat dilihat oleh pelanggan dan laporan yang dapat dilihat oleh manager.

\subsection{Karakteristik Pengguna}

Pada sistem informasi laundry ini nantinya akan digunakan pengguna antara lain Admin, Pelanggan, Pegawai Kurir, Pegawai Kasir, Pegawai Pencuci, Pegawai Penyetrika dan manager. Masing-masing pengguna memiliki hak akses tertentu berdasarkan tugasnya. Berikut keterangan hak akses pengguna secara detail akan dijelaskan pada Tabel 1.

Tabel 1 Kategori pengguna aplikasi

\begin{tabular}{|c|c|c|}
\hline Kategori Pengguna & Tugas & Hak Akses \\
\hline Pelanggan & $\begin{array}{l}\text { - Mengubah profil } \\
\text { - Melakukan registrasi } \\
\text { - Memesan jasa laundry }\end{array}$ & - Ubah profil \\
\hline \multirow[t]{2}{*}{ Kurir } & $\begin{array}{l}\text { - Mengkonfirmasi pengambilan } \\
\text { barang laundry }\end{array}$ & - Konfirmasi pengambilan \\
\hline & $\begin{array}{l}\text { - Mengkonfirmasi pengantaran } \\
\text { barang laundry }\end{array}$ & - Konfirmasi pengambilan \\
\hline Kasir & $\begin{array}{l}\text { - Mengkonfirmasi pembayaran } \\
\text { dari pelanggan }\end{array}$ & - Konfirmasi pembayaran \\
\hline Pencuci & $\begin{array}{l}\text { - Mengkonfirmasi barang yang } \\
\text { selesai dicuci }\end{array}$ & - Konfirmasi selesai proses cuci \\
\hline Penyetrika & $\begin{array}{l}\text { - Mengkonfirmasi barang yang } \\
\text { selesai disetrika }\end{array}$ & - Konfirmasi selesai proses setrika \\
\hline \multirow[t]{3}{*}{ Admin } & - Mengelola master layanan & $\begin{array}{l}\text { - Tambah data layanan } \\
\text { - Ubah data layanan } \\
\text { - Ubah status aktif dan tidak aktif } \\
\text { data layanan }\end{array}$ \\
\hline & - Melihat master pelanggan & - Lihat data pelanggan \\
\hline & - Mengelola master karyawan & $\begin{array}{l}\text { - Tambah data karyawan } \\
\text { - Ubah data karyawan } \\
\text { - Ubah status aktif dan tidak aktif } \\
\text { data karyawan }\end{array}$ \\
\hline Manager & - Melihat laporan transaksi & - Lihat laporan transaksi \\
\hline
\end{tabular}




\subsection{Lingkungan Pengembangan}

Bahasa pemrograman yang digunakan adalah Bahasa pemrograman ASP.NET.

Bahasa ASP.NET digunakan untuk mengembangkan dan menjalankan aplikasi berbasis web. ASP.NET sudah didukung oleh berbagai browser baru, seperti Internet Explorer, Mozila Firefox, Apple Safari, atau bahkan browser di peranti mobile seperti Google Chrome, VlackBerry Smart Phone, dan IPhone.

Tool yang digunakan untuk membangun aplikasi adalah Visual Studio 2015, visual studio merupakan salah satu toll besutan Microsoft yang popular dan dipercaya oleh developer dalam mengembangkan web, aplikasi web, game dan aplikasi mobile yang berbasis Windows. Kini Visual Studio 2015, developer dapat mengembangkan aplikasi di berbagai platform seperti Windows, Windows Phone iOS, dan Android.

SQL Server Management Studio merupakan salah satu komponen dari SQL Server. SQL Server Management Studio digunakan sebagi tempat penyimpanan data, dimana digunakan untuk mengakses, mengkonfigurasi, mengelola dan mengembangkan. Untuk melakukan koneksi ke database diperlukan userid atau password yang terdaftar baik itu SQL Server Account maupun Windows Account.

\subsection{Tahapan}

Sistem informasi laundry ini dibangun menggunakan metodologi waterfall, berikut tahapan tahapan sistem informasi dari metodologi tersebut:

\section{a. Planning}

Tahapan awal yang dilakukan yaitu membuat rencana mengenai kegiatan atau activity plan, bertujuan untuk melakukan kegiatan sesuai dengan aktivitas yang sudah direncanakan.

\section{b. Analysist}

Tahapan yang menghasilkan use case diagram, use case diagram merupakan suatu diagram yang menggambarkan fungsi utama dari sistem dan untuk menggambarkan interaksi antara sistem dan lingkungannya. Berikut use case diagram dari sistem informasi laundry dapat dilihat pada Gambar 3.

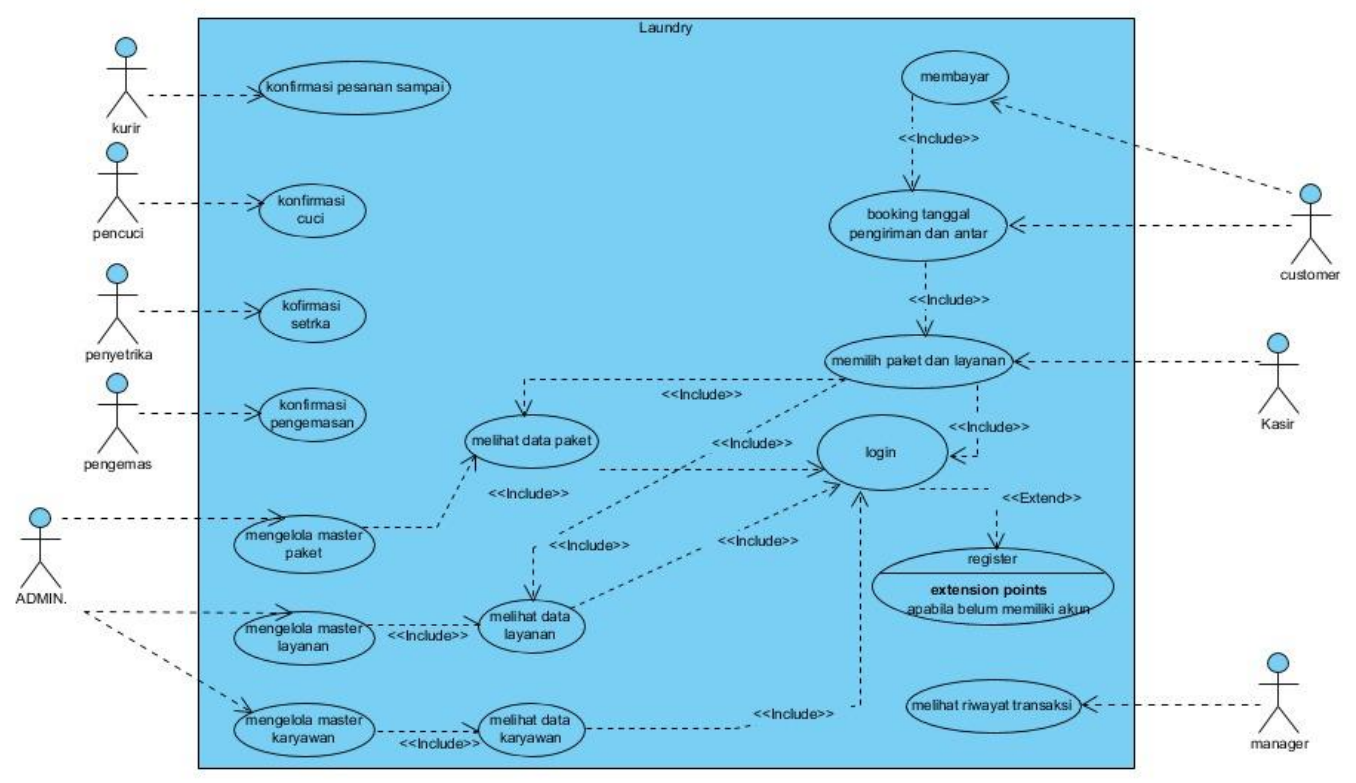

Gambar 3 Use case diagram sistem informasi laundry

c. Design 
Tahapan yang menghasilkan class diagram dan physical data model. Class diagram adalah model statis yang mendukung tampilan statis siitem yang berkembang. Class diagram menunjukkan kelas dan hubungan antar kelas yang tetap konstan di sistem dari waktu ke waktu. Berikut class diagram dari sistem informasi laundry dapat dilihat pada Gambar 4. Sedangkan Physical data model merupakan representasi fisik dari basis data yang akan dibuat. Penggambaran rancangan physical data model memperlihatkan struktur penyimpanan data pada basis data yang digunakan serta hubungan diantaranya. Berikut physical data model dari sistem informasi laundry dapat dilihat pada Gambar 5.

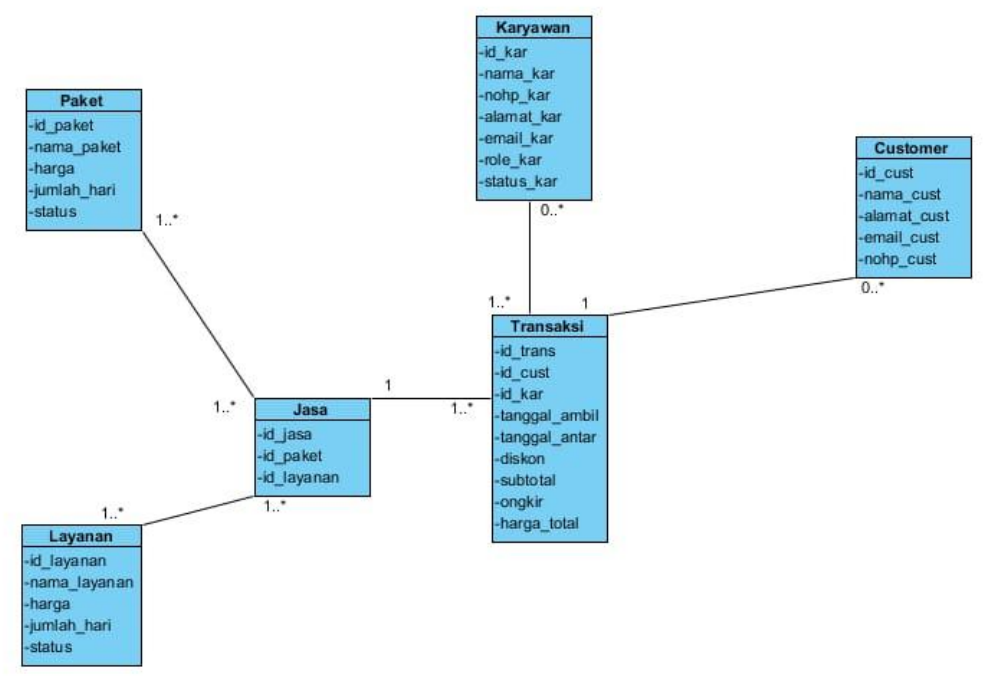

Gambar 4 Class diagram sistem informasi laundry

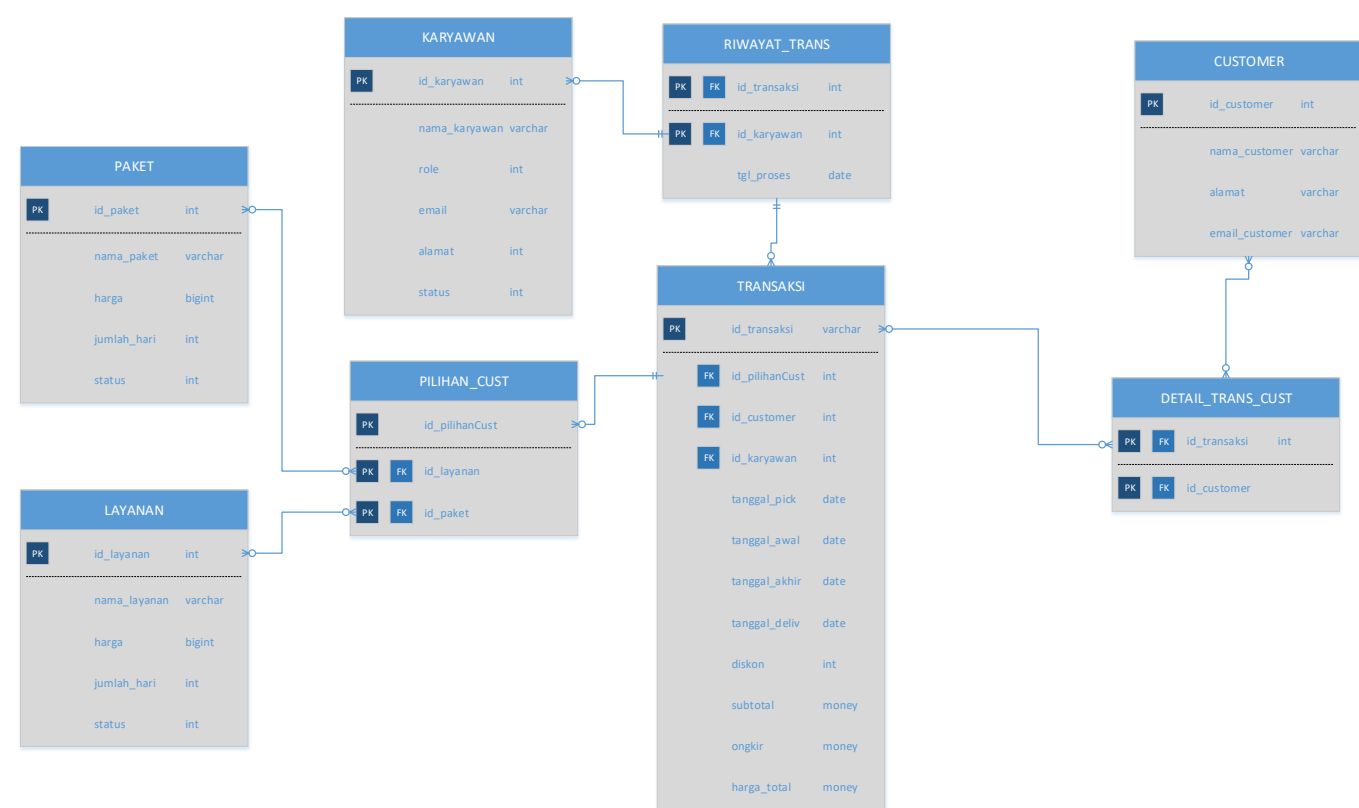

Gambar 5 Physical data model pada sistem informasi laundry

\section{d. Implementation}

Tahap ini mulai dilakukan proses coding atau melakukan implementasi dari tahap sebelumnya, hasil tahap implementasi dapat dilihat dari user interface yang merupakan bentuk tampilan dari aplikasi yang berhubungan secara langsung dengan pengguna, bentuk tampilan yang dibuat hendaknya mudah dimengerti oleh pengguna, sehingga 
pengguna akan mudah untuk menggunakan aplikasi tersebut. Adapun beberapa contoh user interface dari aplikasi laundry sebagai berikut:

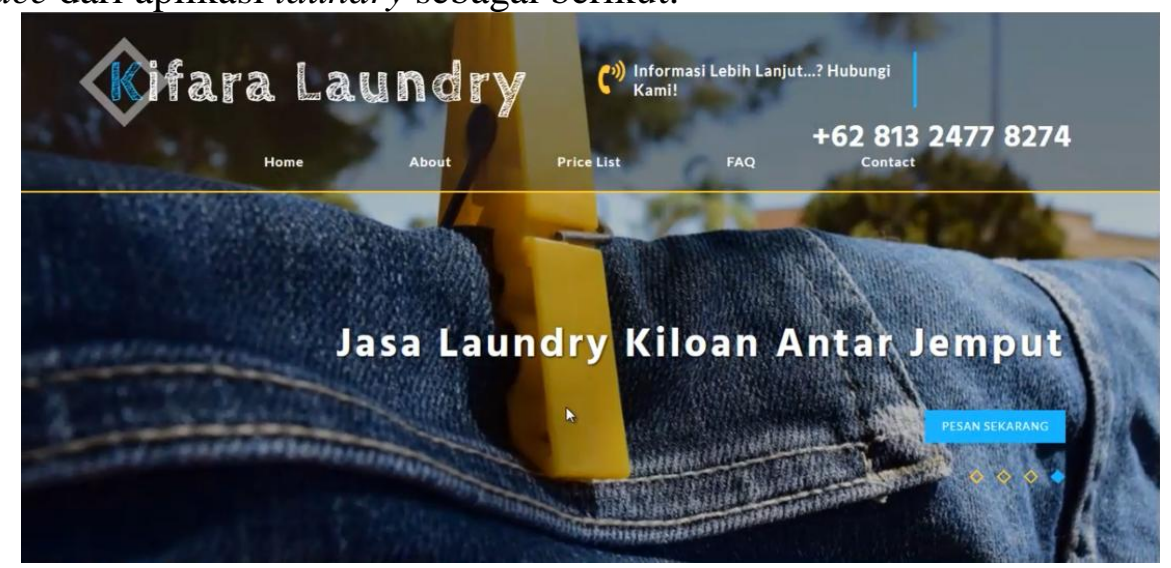

Gambar 6 User Interface Home

Gambar 6 diatas merupakan tampilan utama home atau tampilan awal untuk sistem informasi laundry.

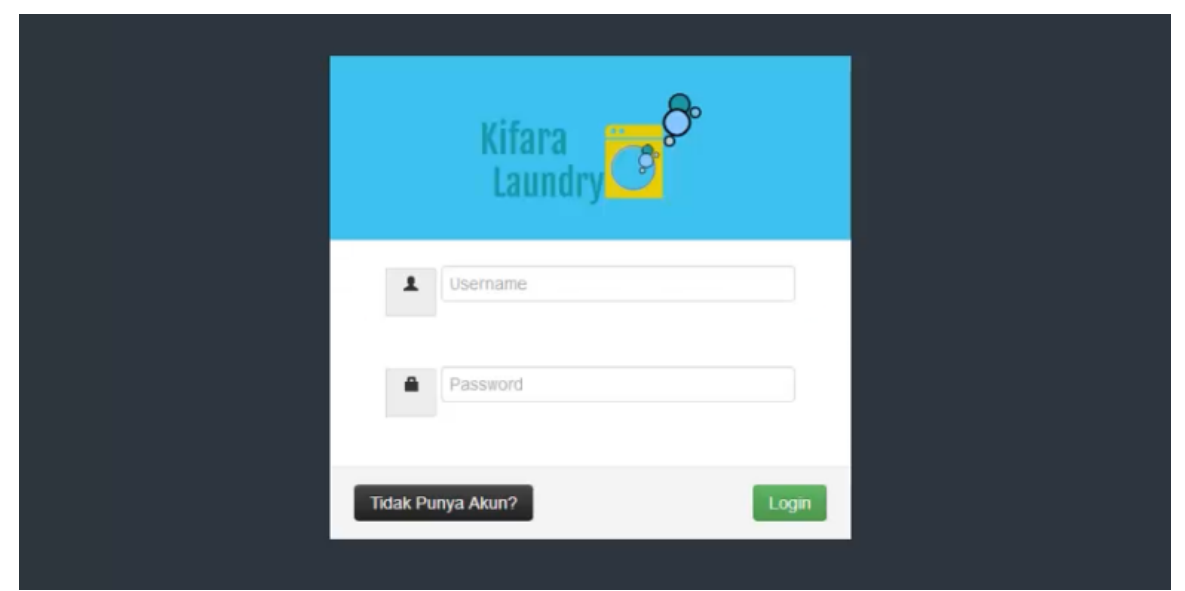

Gambar 7 User Interface Login

Gambar 7 diatas merupakan tampilan login yang ada pada sistem informasi laundry.

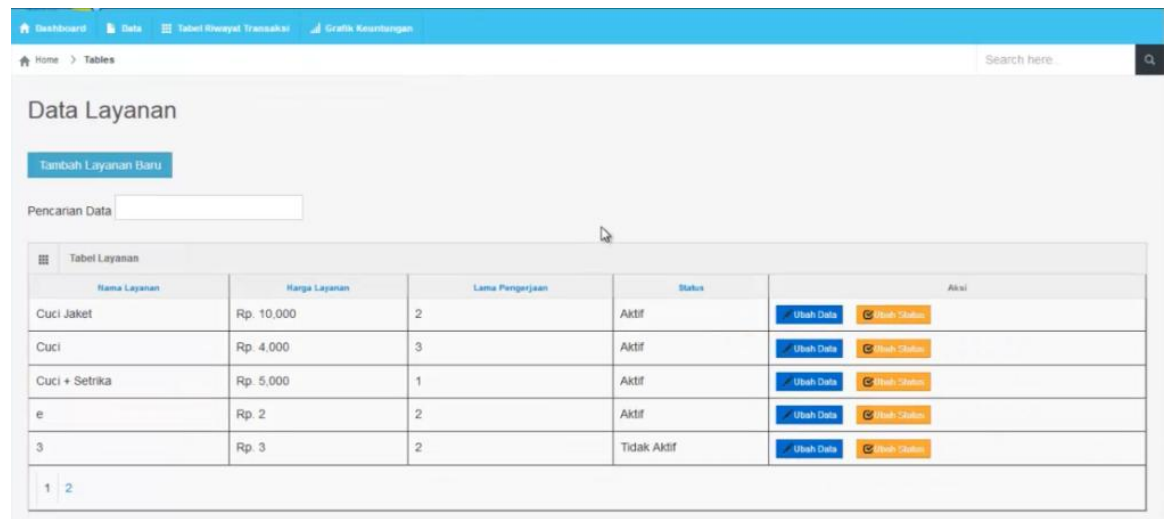

Gambar 8 User Interface Data Layanan

Gambar 8 diatas merupakan tampilan pada menu layanan yang hanya dapat diakses oleh admin, pada halaman ini admin dapat mengolah data layanan. 


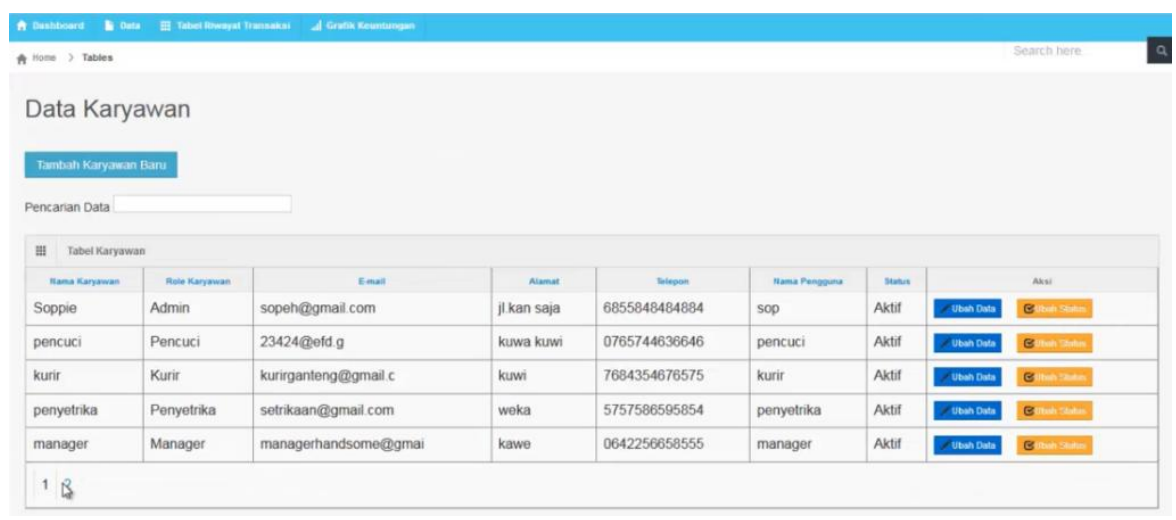

Gambar 9 User Interface Data Karyawan

Gambar 9 diatas merupakan tampilan pada menu karyawan yang hanya dapat diakses oleh admin, pada halaman ini admin dapat mengola data karyawan.

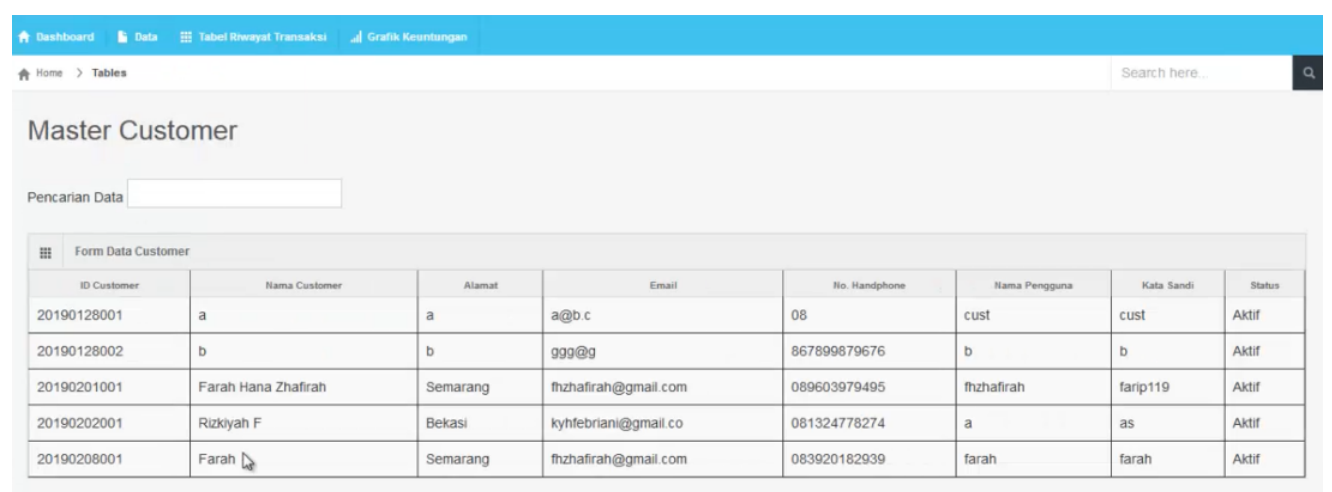

Gambar 10 User Interface Data Pelanggan

Gambar 10 diatas merupakan tampilan pada menu customer yang hanya dapat diakses oleh admin, pada halaman ini admin dapat melihat data pelanggan.

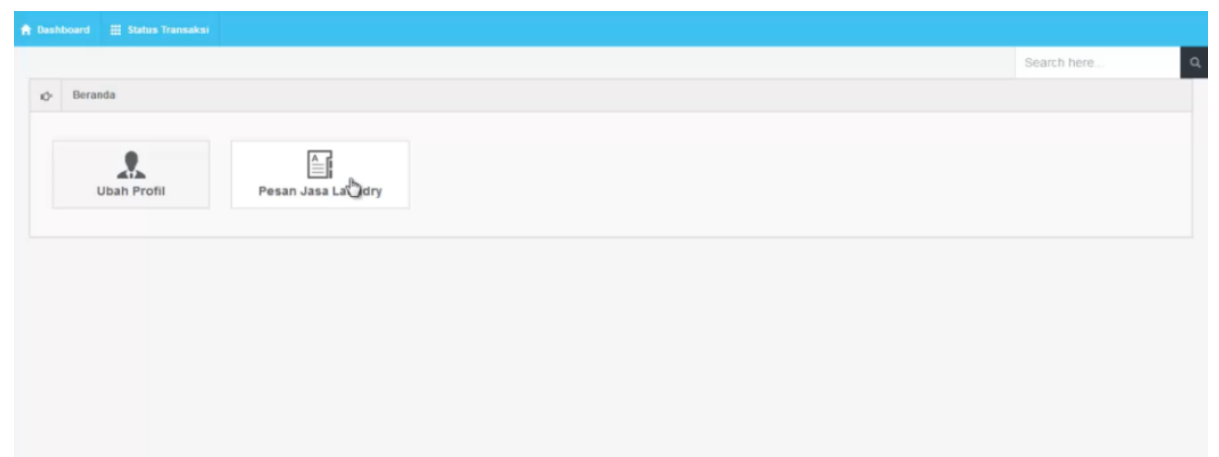

Gambar 11 User Interface Menu Pelanggan

Gambar 11 diatas merupakan tampilan menu customer yang hanya dapat diakses oleh pelanggan, pada halaman ini pelanggan dapat mengubah profil dan melakukan transaksi pemesanan jasa laundry. 


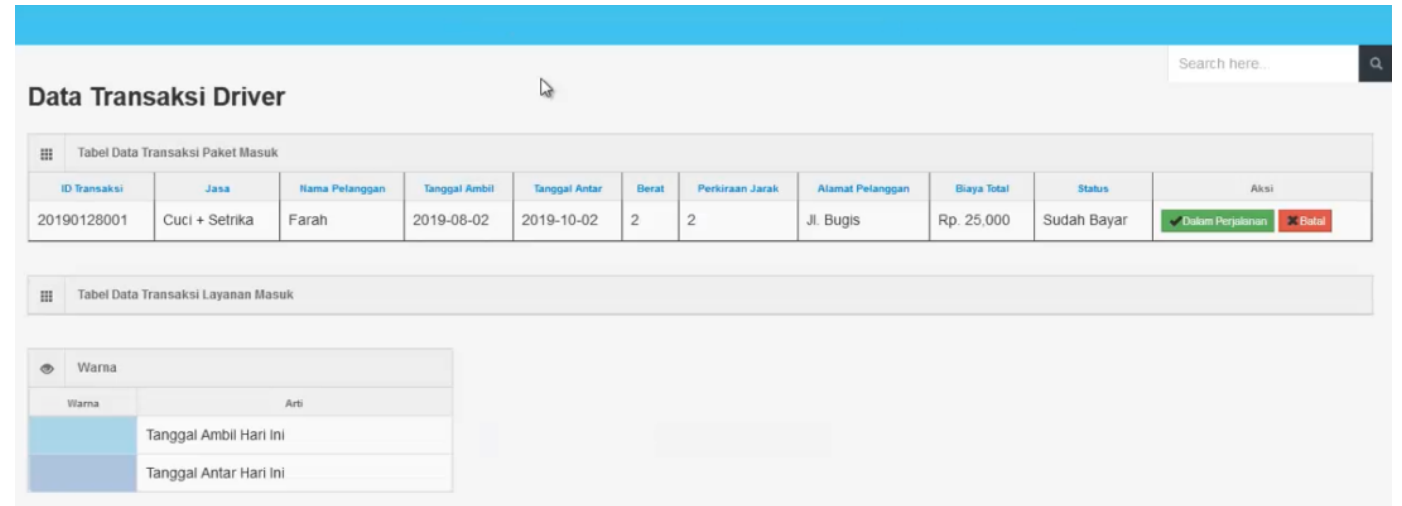

Gambar 12 User Interface Konfirmasi Kurir

Gambar 12 diatas merupakan tampilan data transaksi driver yang hanya dapat diakses oleh kurir, pada halaman ini kurir akan melakukan konfirmasi selesai mengenai pengambilan dan pengantaran barang laundry.

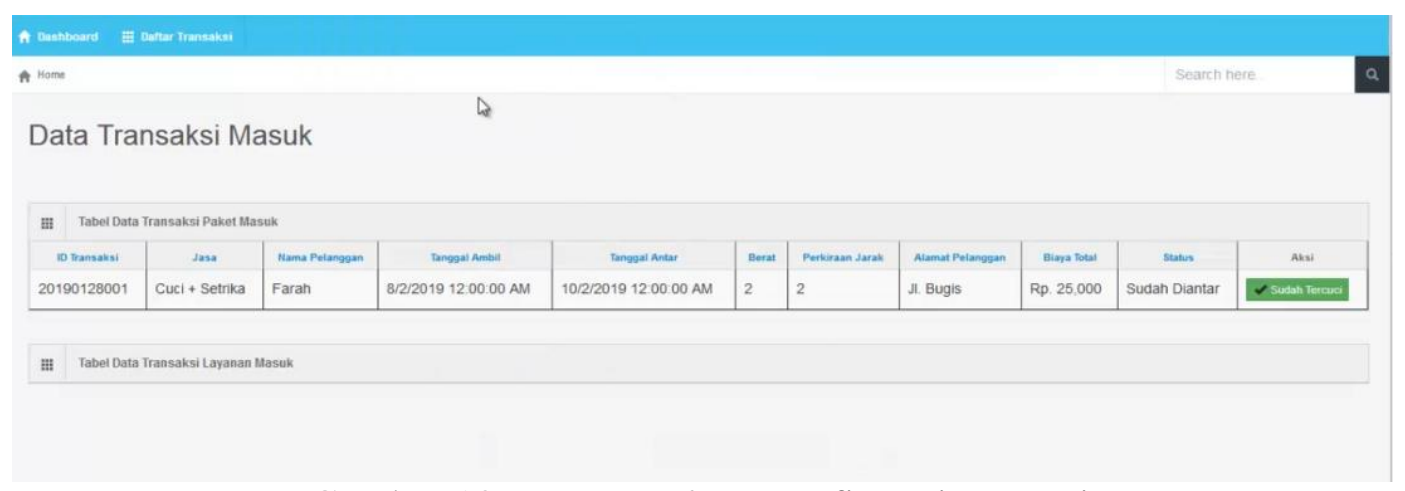

Gambar 13 User Interface Konfirmasi Pencuci

Gambar 13 diatas merupakan tampilan data transaksi masuk yang hanya dapat diakses oleh pegawai pencuci, pada halaman ini pegawai pencuci akan melakukan konfirmasi selesai apabila barang laundry sudah selesai dicuci.

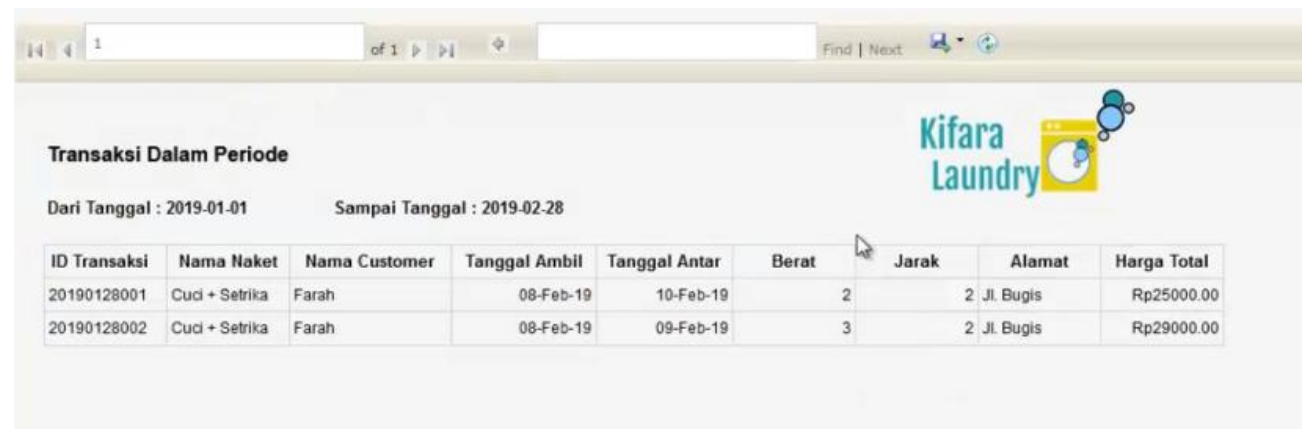

Gambar 14 User Interface Laporan Transaksi

Gambar 14 diatas merupakan tampilan dari laporan transaksi yang hanya dapat diakses oleh manager.

\section{Kesimpulan}

Proses pencatatan transaksi laundry didaerah Sungai Bambu, Jakarta Utara yang masih dilakukan secara manual atau masih mencatat transaksi di nota, proses tersebut memakan waktu yang cukup lama, dikarenakan pegawai harus menghitung total harga dari 
berat barang yang akan di laundry. Selain pencatatan proses transaksi, pembuatan laporan pun masih menggunakan cara manual, sehingga hal ini dapat menyebabkan kerusakan atau hilangnya data yang dicatat. Laundry ini juga menyediakan berbagai layanan jasa laundry yang sewaktu-waktu dapat ditambahkan. Dengan adanya penelitian ini diharapkan dapat menghilangkan proses pencatatan dengan cara manual, menghitung total harga dari berat barang laundry, menghasilkan laporan pendapatan secara otomatis dan admin atau pemilik laundry dapat melakukan custom pada jasa layanan yang akan disediakan.

\section{Saran}

Dari analisa sistem yang telah dibuat, bahwa perlu dikembangkan untuk dapat memenuhi kebutuhan pengguna.

\section{Daftar Pustaka}

[1] W. Putra, "Visual Studio 2015 - Tool Besutan Microsoft yang Mendukung Pengembangan Aplikasi Mobile Multiplatform," 17 September 2015. [Online].

Available: https://teknojurnal.com/visual-studio-2015/.

[2] "What is SQL Server Management Studio (SSMS)?," 09 September 2019. [Online]. Available: https://docs.microsoft.com/en-us/sql/ssms/sql-server-management-studiossms?view $=$ sql-server-ver 15 .

[3] Ramlah,Marwana,Sukriadi.(2019).Sistem Informasi Jasa Laundry Di Kota Makassar Berbasis Web. Jurnal informatika dan Multimedia STIMED Nusa Palapa

[4] Simargolang, M. Y., \& Nasution, N. (2018). Aplikasi Pelayanan Jasa Laundry Berbasis WEB (Studi Kasus: Pelangi Laundry Kisaran). Jurnal Teknologi Informasi, 2(1), 9-14.

[5] Setiyawati, Y. D., Isnanto, R. R., \& Martono, K. T. (2016). Pembuatan Aplikasi AntarJemput Laundry Berbasis Web Service pada Platform Android. Jurnal Teknologi dan Sistem Komputer, 4(1), 150-158.

[6] Kamil, H., \& Duhani, A. (2016). Pembangunan Sistem Informasi Pelayanan Jasa Laundry Berbasis Web Dengan Fitur Mobile Pada 21 Laundry Padang. Prosiding Semnastek.

[7] D. Moraldo.(2019).Bab III Metodologi Penelitian 3.1 Diagram Alir Proses Perancangan. Academia

[8] Kurniawan, "Pengertian Sistem Informasi," 4 Juli 2019. [Online]. Available: https://www.gurupendidikan.co.id/pengertian-sistem-informasi/. [Diakses 15 November 2019].

[9] Hidayat, "Metode Penelitian: Pengertian, Tujuan, Jenis," 3 Februari 2017. [Online]. Available: https://www.statistikian.com/2017/02/metode-penelitian-metodologipenelitian.html. [Diakses 15 November 2019].

[10] Denis, B. H. Wixom and D. Tegarden.(2009). System Analysis and Design. Third Edition, Hoboken: John Wiley \& Sons

[11] Denis, B. H. Wixom, R. M. Roth and A. Dennis.(2012). System Analysis and Design. Fifth Edition, Hoboken: John Wiley \& Sons, Inc. 